\title{
The Effectiveness of Placental Drainage in the Active Management of the Third Stage against the Duration of Three Childbirths in the Independent Practice of Midwives in Banda Aceh City
}

\author{
Gustiana Gustiana*, Novemi Novemi, Yusnaini Yusnaini, Kartinazahri Kartinazahri, lin Fitraniar \\ Department of Midwifery, Polytechnic of Health, Ministry of Health, Aceh, Indonesia
}

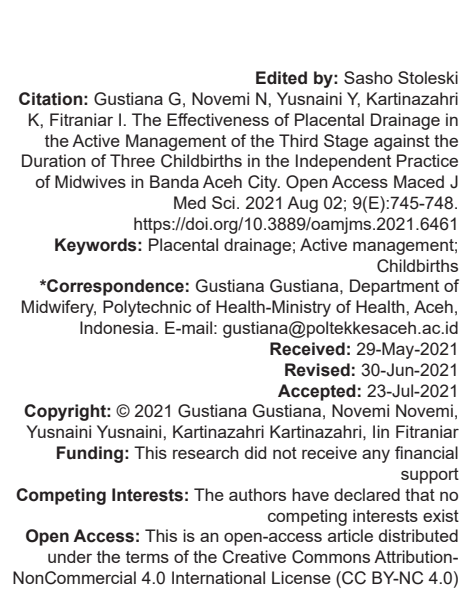

Introduction

Overall health status indicators have improved significantly over the past three decades in Indonesia [1]. The effort to reduce maternal mortality rate (MMR) is one of the targets of the Ministry of Health. Maternal mortality is very high in many parts of the world, including in Indonesia [2]. Recent estimates by the Government of Indonesia show a MMR of 305 per $1,00,000$ live births in 2015 [3]. The MMR in Indonesia is still relatively high. In 2015 , there were 4,999 cases recorded, and in 2016 it fell to 4,912 cases and then dropped sharply in 2017 to 1,712 cases. According to a World Health Organization (WHO) report, the direct causes of maternal death occur during and after childbirth. About $75 \%$ of maternal deaths result from bleeding, infection, or high blood pressure during pregnancy. MMR is an indicator to see the health status of women and is one of the components of the development index and quality of life index [4]. Massive bleeding is the leading cause of maternal mortality worldwide. Factors that cause postpartum hemorrhage include uterine atony, retained placenta, lacerations of the birth canal, and blood disorders. Among direct obstetric causes, bleeding was the most common (36\% of direct causes), followed by hypertensive disorders such as eclampsia (17\%) [5], [6]. The highest mortality rate is at birth and $24 \mathrm{~h}$ postpartum [7]. The interventions most effective in saving lives should ensure emergency care at birth, namely, the presence of trained personnel at birth and timely access [8], [9]. Postpartum hemorrhage is a sudden and unpredictable occurrence. Current evidence shows that health care workers, equipment, and injecting safety are assured and that performing active stage III management reduces postpartum hemorrhage. Active third stage management is performed to prevent bleeding, accelerate the separation process and deliver the placenta by administering uterotonics within the first minute after birth and performing controlled cord stretching for $15 \mathrm{~s}$. The implementation of labor care to accelerate the release of the placenta and avoid bleeding is required compared to the procedure with 
clamped umbilical cord and unclamped umbilical cord (placental drainage) integrated into the third stage of management against the third stage in the Midwives Independent Practice (PMB). Based on the background above, the researcher is interested in knowing the effectiveness of placental drainage in the active management of the third stage of labor.

\section{Methods}

This study used a Quasi Experiment design with a post-test control design. This research was conducted for 12 weeks at the PMB in Banda Aceh, namely, mothers who gave birth at PMB Erni Munir and PMB Mutia Yacob. The sampling technique was purposive sampling. The sample in this study amounted to thirty mothers giving birth, divided into two groups, namely the treatment group with placental drainage as many as 15 mothers and respondents with cord clamping as many as 15 mothers. With the inclusion criteria, the mother is willing to be a respondent, the vital signs of normal mothers, single and live fetuses, term pregnancy, and an interpretation of average fetal weight $\geq 2500 \mathrm{~g}$. Data analysis used the MannWhitney test, with a confidence level of $95 \%$.

\section{Results}

The results of research on the effectiveness of placental drainage in stage three management for the duration of three deliveries at the PMB in Banda Aceh City with thirty mothers giving birth, divided into two treatment groups, namely, placental drainage of 15 mothers giving birth and 15 mothers giving birth with rope clamping center. The results of measurements on the dependent and independent variables, namely, placental drainage and umbilical cord clamping on the duration of the third stage in labor, are as follows:

Based on Table 1, it is known that of the thirrty mothers who gave birth, most of the mothers had no risk age as many as 17 people (56.7\%), and multiparity

Table 1: Frequency distribution based on characteristics of mothers giving birth at PMB Erni Munir and PMB Mutia Yacob in Banda Aceh Municipality in 2018

\begin{tabular}{lll}
\hline Characteristics & Frequency & $(\%)$ \\
\hline Age & 13 & 43.3 \\
$\quad$ Risky & 17 & 56.7 \\
$\quad$ No risky & & \\
Parity & 10 & 33.3 \\
$\quad$ Primipara & 18 & 60.0 \\
Multipara & 2 & 6.7 \\
$\quad$ Grandemultipar &
\end{tabular}

parity was 18 people (60\%). Furthermore, the data analysis was performed using the MannWithney test statistical test.

Based on Table 2, it was found that the length of the three stages required by mothers to give birth with placental drainage was an average of $4.47 \mathrm{~min}$ with a standard deviation value of 0.516 , while the length of three stages required by mothers to give birth with umbilical cord clamping was an average of $5.40 \mathrm{~min}$ with a standard deviation of 0.828 . The statistical test results obtained $p=0.001$, meaning a difference in effectiveness between the placenta drainage group and the umbilical cord clamping group.

Table 2: Effectiveness of placental drainage and umbilical cord clamping on the duration of three deliveries at PMB Erni Munir and PMB Mutia Yacob

\begin{tabular}{llll}
\hline Length of stage three & Mean & $\mathrm{p}$-value & $\mathrm{n}$ \\
\hline Placental drainage & 4.47 & 0.001 & 15 \\
Cord clamping & 5.40 & 0.828 & 15 \\
\hline Source: Primary data processing, PMB: Midwives Independent Practice.
\end{tabular}

\section{Discussion}

The results showed that the average length of three stages with placental drainage was $4.33 \mathrm{~min}$ shorter than without placental drainage was $6.22 \mathrm{~min}$, with a difference of $1.89 \mathrm{~min}$. When viewed from the effect, placental drainage has an effect of 1.94 times greater than without placental drainage. Midwives routinely drain the placenta by clamping the umbilical cord and collecting blood in the placenta container. Active management consists of measures to reduce the duration of the triple stage and the blood loss that occurs during this period [10]. Active management of the third stage of labor using the umbilical cord drainage method significantly reduces postpartum blood loss and the duration of the third stage [11]. This action is to drain the placenta and reduce its volume, thereby facilitating removing the placenta from the uterine wall. Passive management of the third stage of labor, the umbilical cord, is immediately clamped and cut after delivery to allow other active management interventions. In waiting for management, cord clamping is usually performed after the cord has stopped pulsating. Although the two practices appear to have no difference in their effect on the mother, immediate clamping can reduce the amount of placental blood delivered to the baby. It is estimated that early umbilical cord clamping prevents $20-50 \%$ of fetal blood from flowing from the placenta to the baby. Reduced blood flow results in lower levels of hematocrit and hemoglobin in newborns and can affect iron anemia on infant growth. Several studies have shown the potential for increased neonatal respiratory distress due to premature cord clamping. 19 Placental blood drainage as part of active management of 
Stage III labor effectively reduces duration and blood loss [12]. In the management of third-stage labor using the umbilical cord drainage method, it was found that there was a significant reduction in postpartum blood loss and the duration of the third stage in patients with expected vaginal delivery [13]. Some studies also note that cord drainage was found to reduce the third stage of labor by about $3 \mathrm{~min}$, with a slight decrease in blood loss [14]. Cord drainage shortens the duration of the third stage of labor; this method appears to be safe and does not increase postpartum complications [15]. Observational studies have shown that umbilical cord drainage can shorten the duration of the third stage and reduce blood loss during vaginal delivery [16]. Placental drainage of fetal blood before spontaneous placental delivery at the time of cesarean delivery significantly reduces the incidence of fetomaternal transfusion [17]. Observational studies have shown that umbilical cord drainage can shorten the duration of the third stage and reduce blood loss during vaginal delivery [18]. Cord clamping reduces the volume of placental blood transfusion and reduces infant blood volume at birth by about $20 \%$ for term infants [19]. Active management requires consideration of costs, storage requirements, equipment, trained personnel, and quality of health facilities and facilities. Active management also depends on the availability of uterotonic drugs, syringes, and needles.

\section{Conclusion}

Placental drainage was more effective than umbilical cord clamping to shorten the third stage length with $p=0.001$. The duration of the third stage for the mother to give birth after placental drainage was $4.7 \mathrm{~min}$. The third stage for mothers to give birth to which the umbilical cord is clamped is $5.40 \mathrm{~min}$.

\section{References}

1. Nababan HY, Hasan M, Marthias T, Dhital R, Rahman A, Anwar I. Trends and inequities in use of maternal health care services in Indonesia, 1986-2012. Int J Womens Health. 2019;10:11-24. https://doi.org/10.2147/ijwh.s144828

PMid:29343991

2. World Health Organization. Trends in Maternal Mortality: 1990 to 2013 Estimates by WHO, UNICEF, UNFPA, The World Bank and the United Nations Population Division. Geneva: World Health Organization; 2013. https://doi.org/10.1111/padr.12033

3. Statistics Indonesia (Badan Pusat Statistik-BPS). Profil Penduduk Indonesia Hasil SUPAS. Jakarta: Badan Pusat Stastistik; 2015.

4. Sumarmi S. Socio-ecological model of health behavior and continuum of care approach to reduce maternal mortality.
Indonesia J Public Health. 2017;12(1):129-41. https://doi. org/10.20473/ijph.v12i1.2017.129-141

5. World Health Organization. WHO Recommendations for the Prevention and Treatment of Postpartum Haemorrhage. Geneva: World Health Organization; 2012.

6. Say L, Chou D, Gemmill A, Tunçalp Ö, Moller AB, Daniels J, et al. Global causes of maternal death: A WHO systematic analysis. Lancet Glob Health. 2014;2(6):e323-33. https://doi. org/10.1016/s2214-109x(14)70227-x

PMid:25103301

7. Li XF, Fortney JA, Kotelchuck M, Glover LH. The postpartum period: The key to maternal mortality. Int J Gynaecol Obstet. 1996;54(1):1-10. https://doi.org/10.1016/0020-7292(96)02667-7 PMid:8842811

8. Goldenberg RL, McClure EM. Maternal, fetal and neonata mortality: Lessons learned from historical changes in high income countries and their potential application to low-income countries. Matern Health Neonatol Perinatol. 2015;1:3. https:// doi.org/10.1186/s40748-014-0004-z

PMid:27057321

9. Chowdhury ME, Botlero R, Koblinsky M, Saha SK, Dieltiens G, Ronsmans C. Determinants of reduction in maternal mortality in Matlab, Bangladesh: A 30-year cohort study. Lancet. 2007;370(9595):1320-8. https://doi.org/10.1016/ s0140-6736(07)61573-6 PMid: 17933646

10. Wood J, Rogers J. The third stage of labour In: Alexander J Levy V, Roth C, editors. Midwifery Practice: Core Topics 2. London: MacMillan Press Ltd.; 1997. https://doi. org/10.1007/978-1-349-14529-4_8

11. Afzal MB, Bushra N, Waheed K, Sarwar A, Awan NU. Role of placental blood drainage as a part of active management of third stage of labour after spontaneous vaginal delivery. J Pak Med Assoc. 2019;69(12):1790-3. https://doi.org/10.5455/ jpma.302642458 PMid:31853104

12. Roy P, Sujatha MS, Bhandiwad A, Biswas B, Chatterjee A Placental blood drainage as a part of active management of third stage of labour after spontaneous vaginal delivery. J Obstet Gynaecol India. 2016;66 Suppl 1:242-5. https://doi.org/10.1007/ s13224-016-0857-3

PMid:27651611

13. Jangsten $E$, Mattsson LÅ, Lyckestam I, Hellström AL, Berg M. A comparison of active management and expectant management of the third stage of labour: A Swedish randomised controlled trial. BJOG. 2011;118(3):362-9. https://doi. org/10.1111/j.1471-0528.2010.02800.x PMid:21134105

14. Soltani H, Poulose TA, Hutchon DR. Placental cord drainage after vaginal delivery as part of the management of the third stage of labour. Cochrane Database Syst Rev. 2011;7(9):CD004665. https://doi.org/10.1002/14651858.cd004665.pub3 PMid:21901693

15. Jongkolsiri $P$, Manotaya S. Placental cord drainage and the effect on the duration of third stage labour, a randomized controlled trial. J Med Assoc Thai. 2009;92(4):457-60. PMid:19374293

16. Wu HL, Chen XW, Wang P, Wang QM. Effects of placental cord drainage in the third stage of labour: A metaanalysis. Sci Rep. 2017;7(1):7067. https://doi.org/10.1038/ s41598-017-07722-7

PMid:28765609

17. Leavitt BG, Huff DL, Bell LA, Thurnau GR. Placental drainage of fetal blood at cesarean delivery and feto maternal transfusion: A randomized controlled trial. Obstet 
Gynecol. 2007;110(3):608-11. https://doi.org/10.1097/01. aog.0000277262.80793.0d

PMid:17766607

18. Sharma JB, Pundir P, Malhotra M, Arora R. Evaluation of placental drainage as a method of placental delivery in vaginal deliveries. Arch Gynecol Obstet. 2005;271(4):343-5. https://doi. org/10.1007/s00404-004-0619-9
PMid: 15034720

19. Begley CM, Gyte GM, Devane D, McGuire W, Weeks A. Active versus expectant management for women in the third stage of labour. Cochrane Database Syst Rev. 2011;11:CD007412. https://doi.org/10.1002/14651858.cd007412.pub3

PMid:22071837 